\title{
RESEARCH IN SP \\ PHYSICALACTI \\ Women's exercise experiences in women only gyms: an examination within the framework of self determination theory and feminist cultural studies
}

Autor(es): $\quad$ Öztürk, Pnar

Publicado por: Imprensa da Universidade de Coimbra

URL persistente:

URI:http://hdl.handle.net/10316.2/34973

DOI:

DOI:http://dx.doi.org/10.14195/2182-7087_5_12

Accessed : $\quad$ 26-Apr-2023 10:38:07

A navegação consulta e descarregamento dos títulos inseridos nas Bibliotecas Digitais UC Digitalis, UC Pombalina e UC Impactum, pressupõem a aceitação plena e sem reservas dos Termos e Condições de Uso destas Bibliotecas Digitais, disponíveis em https://digitalis.uc.pt/pt-pt/termos.

Conforme exposto nos referidos Termos e Condições de Uso, o descarregamento de títulos de acesso restrito requer uma licença válida de autorização devendo o utilizador aceder ao(s) documento(s) a partir de um endereço de IP da instituição detentora da supramencionada licença.

Ao utilizador é apenas permitido o descarregamento para uso pessoal, pelo que o emprego do(s) título(s) descarregado(s) para outro fim, designadamente comercial, carece de autorização do respetivo autor ou editor da obra.

$\mathrm{Na}$ medida em que todas as obras da UC Digitalis se encontram protegidas pelo Código do Direito de Autor e Direitos Conexos e demais legislação aplicável, toda a cópia, parcial ou total, deste documento, nos casos em que é legalmente admitida, deverá conter ou fazer-se acompanhar por este aviso. 
(5) 2014

\section{ANNALS OF \\ RESEARCH IN SPORT AND \\ PHYSICAL ACTIVITY}

FACULDADE DE

CIÊNCIAS DO

DESPORTO E

EDUCAÇÃO FÍSICA DA UNIVERSIDADE DE COIMBRA

IMPRENSA

DA UNIVERISDADE

DE COIMBRA :

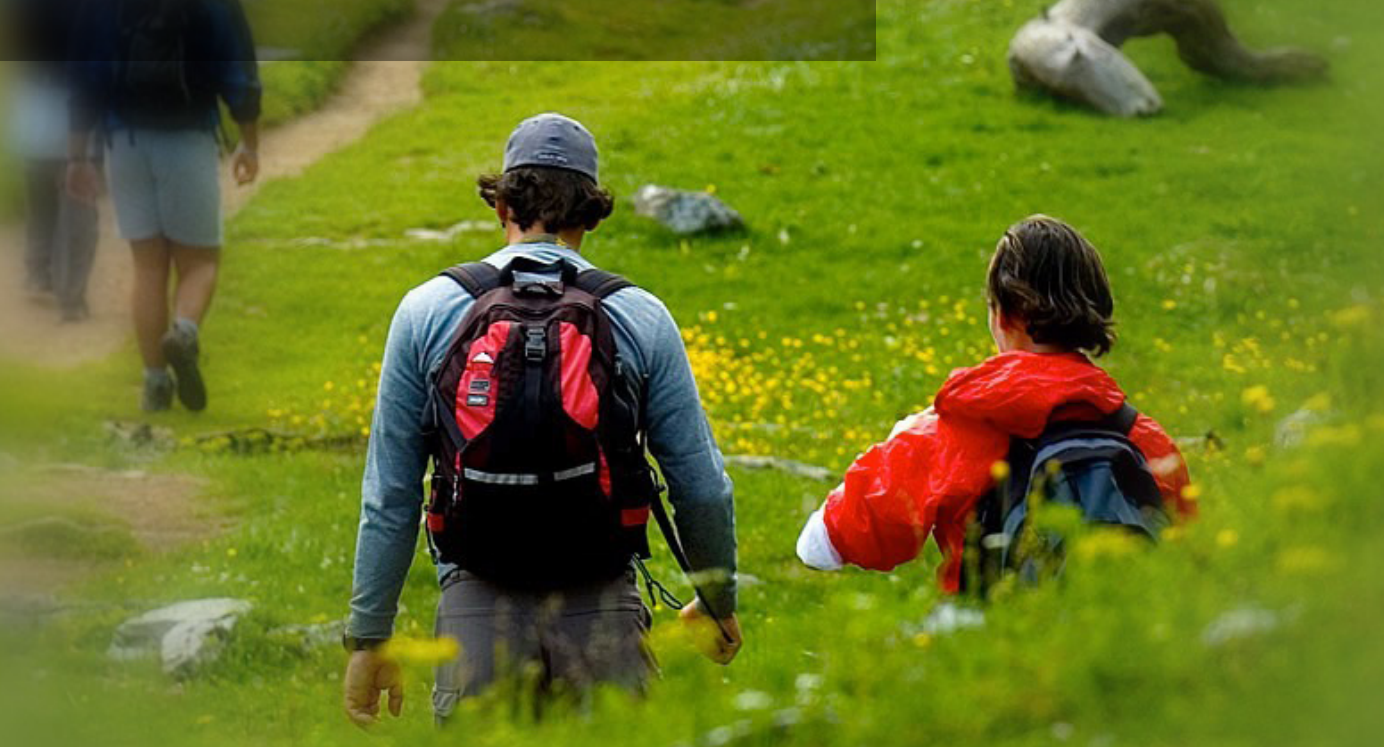


2 • PSICOLOGIA DO DESPORTO / SPORT PSYCHOLOGY

WOMEN'S EXERCISE EXPERIENCES IN WOMEN-ONLY GYMS: AN EXAMIIATION WITHIN THE FRAMEWORK OF SELFDETERMINATION THEORY AND FEMINIST CULTURAL STUDIES 



\author{
PInar Öztürk ${ }^{1}$ \\ pinarozturk@hacettepe.edu.tr
}

Within fitness industry, women-only gyms have become an important market throughout the world in recent years. These spaces represent "male and mirror free exercise spaces" especially for women not prefering the weight-lifting exercises in mainstream gyms and in need of different needs and interests (Craig \& Liberti, 2007). Women's experience of physical activity is closely related to culture and social space (Markula, 1995; Krane et al., 2001). Therefore, it is important to understand the role of gender-segrageted gyms in different cultures such as Turkey which women are frequently in disadvantaged position in social, political and economic life. This research examines the factors that affect the experience of women exercising in women-only gyms within the frame of Self-determination theory (Ryan \& Deci, 2000) and feminist cultural studies (Markula, 1995). In this respect, the study aims at two main issues: (a) How does the socio-contextual environment of women-only gyms effect women's experiences and perceptions of exercising? (b) What kinds of roles do these gyms play in the satisfaction of competence, relatedness and autonomy basic needs?

The data was collected through participant observation and interviews that are based upon qualitative research methods, in GoFit (pseudonym) in Ankara, Turkey (Patton, 2002). 40-90 minutes semi-structured interviews are conducted with 20 women exercise participants of ages 19-58. The data is analysed with content analysis. Peer scrutiny of the research, prolonged engagement, reflexivity and triangulation strategies were employed to enhance the credibility of the study (Patton, 2002). The collected data was sorted into three main categories: (1) Exercise in minimum (intensity of daily life and time of one's own), (2) The structured program (no harm from the equipments and controlled exercises) and (3) Comfort of being in women-only environment (avoidance of body exposure and relatedness). Consequently, women-only gyms have gendered structures enabling the satisfaction of competence, relatedness and autonomy needs and these gendered structures specify the perception of women about exercise.

\title{
REFERENCES
}

Craig, M. L., \& Liberti, R. (2007). "Cause that's what girls do": The making of a feminized gym. Gender \& Society, 21, 5, 676-699.

\footnotetext{
1 Hacettepe University, Faculty of Sport Sciences
} 
Markula, P. (1995). Firm but shapely, fit but sexy, strong but thin: The postmodern aerobicizing female bodies. Sociology of Sport Journal, 12, 424-453.

Krane, V., Waldron, J., Michalenok, J., \& Stiles-Shipley, J. (2001). Body image concerns in female exercisers and athletes: A feminist cultural studies perspective. Women in Sport \& Physical Activity Journal, 10, 1, 17.

Patton, M. (2002). Qualitative evaluation methods. Beverly Hills, CA: Sage Publications.

Ryan, R. M., \& Deci, E. L. (2000). Self-determination theory and the facilitation of intrinsic motivation, social development, and well-being. American Psychologist, 55, 1, 68-78. 